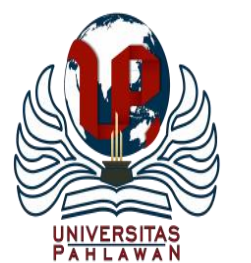

Edukatif : Jurnal Ilmu Pendidikan Volume 3 Nomor 2 Tahun 2021 Halm 487 - 495

EDUKATIF: JURNAL ILMU PENDIDIKAN

Research \& Learning in Education

https:/ledukatif.org/index.php/edukatif/index

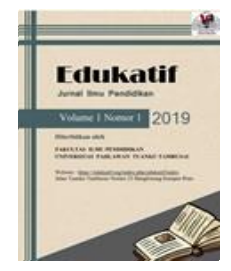

\title{
Penerapan Project Based Learning Berbasis Keterampilan Sosial Mata Pelajaran Kewarganegaraan di Sekolah Menengah Atas
}

\author{
Herpratiwi $^{1 凶}$, Taufiqurrahman ${ }^{2}$, Sugeng Widodo ${ }^{3}$, Refki Effendi ${ }^{4}$ \\ Program Studi Magister Teknologi Pendidikan, Pasca Sarjana Universitas Lampung 1,2,4 \\ Program Studi Pendidikan Geografi, FKIP Universitas Lampung ${ }^{3}$ \\ E-mail : herpratiwi64@yahoo.com ${ }^{1}$, taufiqurrahmanrasyid90@gmail.com ${ }^{2}$, sugeng_geografi@unila.ac.id ${ }^{3}$, \\ refkieffendi@gmail.com ${ }^{4}$
}

\begin{abstract}
Abstrak
Penelitian bertujuan untuk menghasilkan dan menguji produk pembelajaran Project Based Learning berbasis keterampilan sosial mata pelajaran PKN. Masalah yang ada adalah rendahnya keterampilan sosial siswa SMAN 1 Baradatu, Way Kanan Lampung. Penelitian ini merupakan jenis penelitian pengembangan R\&D (Research and Development) model 4-D (four D models) Thiagharajan. Subjek dalam proses pengembangan produk penelitian adalah 5 guru dan 10 siswa SMA Negeri 1 Baradatu, Way Kanan. Proses pengumpulan data menggunakan angket, wawancara, tes dan pengamatan. Angket yang digunakan berupa angket terbuka skala likert dengan jumlah pernyataan 10 soal, wawancara dengan jumlah 13 pertanyaan Tes yang digunakan berupa tes essay sebanyak 15 soal. Analisis hasil belajar dengan uji-t. Keterampilan sosial siswa setelah diajarkan dengan Project Based Learning yang sebelumnya nilai signifikan 7,72 menjadi lebih tinggi dengan nilai signifikan 0,24 .
\end{abstract}

Kata Kunci: Keterampilan Sosial, PKN, Project Based Learning.

\section{Abstract}

The research aims to produce and work on project-based learning products based on skills in PKN subjects. The problem is the low social skills of students at SMAN 1 Baradatu, Way Kanan Lampung. This research is a type of research and development $R \& D$ (Research and Development) model 4-D (four D models) Thiagharajan. The subjects in the research product development process were 5 teachers and 10 students of SMA Negeri 1 Baradatu, Way Kanan. The process of collecting data uses questionnaires, interviews, tests and observations. The questionnaire used was in the form of an open questionnaire on the Likert scale with 10 statements of questions, interviews with 13 questions. The test used was in the form of an essay test of 15 questions. Analysis of learning outcomes with t-test. Students' social skills after being taught with Project Based Learning, which previously had a significant value of 7.72, became higher with a significant value. 0.24 .

Keywords: Social Skills, Civic education, Project Based Learning.

Copyright (c) 2021 Herpratiwi, Taufiqurrahman, Sugeng Widodo, Refki Effendi

$\triangle$ Corresponding author

Email : herpratiwi64@yahoo.com

DOI $\quad$ : https://doi.org/10.31004/edukatif.v3i2.313

ISSN 2656-8063 (Media Cetak)

ISSN 2656-8071 (Media Online)

Edukatif : Jurnal Ilmu Pendidikan Vol 3 No 2 Tahun 2021 p-ISSN 2656-8063 e-ISSN 2656-8071 


\section{PENDAHULUAN}

Pembelajaran merupakan suatu proses pengembangan suatu potensi dan karakter, dilakukan di lembaga pendidikan formal dan tidak formal. Tujuan dari pembelajaran untuk memberikan kesempatan siswa dalam memperbaiki kecerdasan sosial dan spiritual serta tingkah laku, agar siswa dapat hidup secara seimbang dan bermanfaat di masyarakat. Proses tersebut juga diterapkan dalam pembelajaran Pendidikan Kewarganegaraan $(\mathrm{PKn})$ sebagai mata pelajaran yang mempunyai misi mewujudkan good and smart citizen, yaitu untuk mengembangkan kompetensi siswa secara terintegrasi, termasuk keterampilan sosial siswa, (Udin, 2014). Pembelajaran PKn memiliki tiga komponen pendidikan kewarganegaraan yakni pengetahuan kewarganegaraan (civic knowledge), keterampilan kewarganegaraan (civic skills), dan karakter kewarganegaraan (civic dispositions), (Malatuny \& Rahmat, 2020).

Keterampilan sosial merupakan kecakapan untuk berinteraksi, berkomunikasi dan berpartisipasi dalam kelompok. Keterampilan sosial perlu didasari oleh kecerdasan personal berupa kemampuan mengontrol diri, percaya diri, disiplin, dan tanggung jawab. Keterampilan sosial dapat dikelompokan dalam empat kelompok yang saling berkaitan, yaitu: 1). keterampilan dasar berkomunikasi; berusaha untuk saling mengenal, ada kontak mata, berbagi informasi dan material; 2). Keterampilan komunikasi: mendengar dan berbicara secara bergiliran, melembutkan suara (tidak membentak), meyakinkan orang untuk dapat mengemukakan pendapat, mendengarkan sampai orang tersebut menyelesaikan pembicaraan; 3). Keterampilan dalam membangun tim/kelompok, mengakomodasi pendapat orang, bekerjasama, saling menolong, saling memperhatikan; 4). Keterampilan menyelesaikan masalah, empati, mengendalikan diri, memikirkan orang lain, taat terhadap kesepakatan, mencari jalan keluar dengan berdiskusi, respek terhadap pendapat yang berbeda,(Maryani, 2012).

Civic skill merupakan keterampilan yang dikembangkan dari pengetahuan kewarganegaraan agar pengetahuan yang diperoleh menjadi sesuatu yang bermakna karena dapat dimanfaatkan dalam menghadapi masalah-masalah bermasyarakat, berbangsa, dan bernegara, (Udin, 2014). Warga negara yang dapat menjelaskan bagaimana sesuatu seharusnya berjalan, misalnya sistem pemerintahan presidensil, sistem cheks and balances, dan sistem hukum, maka mereka akan memiliki kemampuan yang lebih baik untuk mencari dan mengoreksi fungsi-fungsi yang tidak beres. Warga negara juga perlu memiliki kemampuan untuk menganalisis hal-hal tertentu sebagai komponen-komponen dan konsekuensi cita-cita, proses-proses sosial, ekonomi, atau politik, dan lembaga-lembaga. Kemampuan dalam menganalisis memungkinkan seorang membedakan antara fakta dengan opini atau antara cara dengan tujuan. Hal ini juga membantu warga negara dalam mengklasifikasi berbagai macam tanggung jawab seperti tanggung jawab publik dan privat, atau antara para pejabat baik yang dipilih atau diangkat dengan warga negara biasa".

Berdasarkan hasil pra penelitian, ditemukan permasalahan sebagai berikut: 1) pada saat diskusi, pembelajaran didominasi oleh beberapa siswa. 2) Pada saat salah satu kelompok presentasi, kelompok lain cenderung tidak menyimak dan kurang menghargai pendapat dari kelompok lain. 3) Pada saat presentasi kelompok siswa hanya sebatas membaca hasil kerja peserta tanpa ada komunikasi secara verbal atau visual dalam diskusi, 4) Banyak materi ataupun bahan yang didapat siswa adalah dari buku saja. 5) Siswa tidak memberikan sikap yang baik kepada pendidik dan siswa lainnya.

Selain itu, hasil pembelajaran siswa tentang pemahaman Hak Asasi Manusia tidak maksimal. Berdasarkan hasil pre test yang dilakukan pada kelas XI SMA Negeri 1 Baradatu, ditemukan data sebagai berikut: 1) hampir $78 \%$ siswa tidak memahami pemahaman tentang pengetahuan dasar konsep HAM. 2) Siswa tidak dapat memberikan contoh-contoh HAM dalam kehidupan sehari-hari. 
3) Siswa tidak dapat mengaktualisasikan hubungan pembelajaran dengan konsep materi yang telah dipelajari. 4) Siswa mendapatkan nilai materi HAM di bawah rata-rata. Berdasarkan hal tersebut, maka perlu dikembangkan PJBL berbasis keterampilan sosial.

Dalam era new normal seperti saat ini, terdapat beberapa metode pembelajaran yang dapat digunakan antara lain yaitu 1) Project Based Learning, 2) Daring Method, 3) Luring Method, 4) Home Visit Method, dan 5) Blended Learning. Project Based Learning berbasis keterampilan sosial dapat melatih keterampilan bekerjasama dan berkomunikasi sehingga siswa mampu hidup secara berkolaboratif dan penuh kepercayaan diri dalam hidup dengan lingkungan sekitar (Anis Shofatun, Muslimin Ibrahim, 2016). Project Based Learning berbasis keterampilan social dilahirkan dari paham konstruktivis, yaitu konstruksi kognitif melalui aktivitas siswa yang meliputi keterampilan ataupun sikap ilmiah yang bermakna melalui pengalaman nyata, (Kurniawan, 2017).

Menurut (Trianto, 2014), Project Based Learning adalah sebuah model inovatif, yang menekankan belajar kontekstual melalui kegiatan-kegiatan yang kompleks. Keterampilan sosial adalah kemampuan individu untuk berkomunikasi efektif dengan orang lain baik secara verbal maupun non verbal sesuai dengan situasi dan kondisi yang ada pada saat itu, dimana keterampilan ini merupakan perilaku yang dipelajari. Keterampilan sosial merupakan keterampilan untuk berinteraksi, berkomunikasi, dan beradaptasi, dalam kelompok. Keterampilan sosial membawa remaja untuk lebih berani berbicara, mengungkapkan setiap perasaan atau permasalahan yang dihadapi dan sekaligus menemukan penyelesaian yang adaptif, sehingga mereka tidak mencari pelarian ke hal-hal lain yang justru dapat merugikan diri sendiri maupun orang lain. Keterampilan sosial perlu didasari oleh kecerdasan personal berupa kemampuan mengontrol diri, percaya diri, disiplin dan tanggung jawab.

Menurut (Arends, 2014), keterampilan sosial adalah perilaku-perilaku yang mendukung kesuksesan hubungan sosial dan memungkinkan individu bekerja bersama orang lain secara efektif. (Gresham, F. M., \& Elliott, 2014) mendefinisikan lima dimensi keterampilan sosial, yaitu: 1) keterampilan berhubungan dengan orang lain (peer relational skills), 2) keterampilan manajemen diri (self-management skills), 3) keterampilan akademik (academic skills), 4) keterampilan mematuhi aturan (compliance skills), dan 5) keterampilan menyatakan pendapat (assertion skills).

Keterampilan sosial cukup erat kaitannya dengan berbagai kemampuan lainnya seperti menjalin kerjasama dalam kelompok, berinteraksi dengan sebayanya, bergabung dalam kelompok, menjalin pertemanan baru, menangani konflik, dan belajar bekerja dalam team. Kurangnya keterampilan sosial berdampak pada rendahnya prestasi akademik siswa tersebut, cenderung kesepian dan menampakkan selfesteem yang rendah, dan ada kemungkinan dropt-out dari sekolah (Muijs, 2018). The Partnership for 21st Century Skills memetakan beberapa life and career skills yang harus dimiliki oleh siswa dari kelas 4-12, diantaranya kemampuan berpikir kritis dan keterampilan sosial, (Saavedra AR, 2012). (Cartledge, Gwendolyn \& Milburn, 2016). keterampilan sosial merupakan perilaku yang perlu dipelajari, karena memungkinkan individu dapat berinteraksi, memperoleh respon positif atau negatif.

Keterampilan sosial adalah keterampilan seperti perencanaan, tanggung jawab, ketegasan, pengambilan keputusan, keterampilan berorientasi emosi, manajemen diri, hubungan teman sebaya, komunikasi dan pemecahan masalah. Anak-anak dengan keterampilan sosial yang baik berhasil membantu orang-orang di sekitar mereka, membangun hubungan yang baik, bekerja, dan berbagi dengan orang-orang yang tinggal bersamanya; anak-anak yang kurang baik dalam hal keterampilan sosial mengalami masalah adaptasi di rumah dan di sekolah; dan menghadapi banyak masalah dengan komunikasi yang sehat dengan orang-orang di sekitar mereka, hubungan sosial, akademik dan kehidupan profesional ( Saide Ozbey et al., 2020). (Kalyoncu, 2020) mendefinisikan keterampilan sosial sebagai perilaku yang dipelajari yang memberikan umpan balik 
positif dari orang lain yang digunakan dalam hubungan interpersonal, melihatnya sebagai jembatan dalam mencapai tujuan, memperlakukannya sebagai perilaku yang dapat diidentifikasi secara obyektif yang dapat ditempatkan dalam hubungan interpersonal dan memberikan yang positif. umpan balik.

Ruang lingkup pembelajaran PKn dalam penelitian ini diharapkan mampu memberikan media atau sarana siswa memiliki nilai sosial yang kuat dan berkarakter sehingga kepribadian siswa dimasyarakat mudah diterima. Berdasarkan kajian di atas, maka perlu pengembangan Project Based Learning berbasis keterampilan sosial untuk pembelajaran pendidikan Kewarganegaraan pada materi kasus pelanggaran HAM secara umum dan punya keingintahuan yang besar terhadap sesuatu yang baru.

\section{METODE PENELITIAN}

Penelitian ini merupakan jenis penelitian pengembangan R\&D (Research and Development) model 4-D (four D models) Thiagharajan. Penelitian bertujuan untuk mengembangkan sebuah produk dan dilakukan uji coba ahli serta lapangan. Subjek dalam proses pengembangan produk penelitian adalah 5 guru dan 10 siswa SMA Negeri 1 Baradatu, Way Kanan. Waktu penelitian bulan Oktober 2020 sampai Januari 2021. Peran guru dan siswa dalam penelitian memberikan informasi tentang permasalahan pembelajaran di sekolah serta memberikan tanggapan terhadap produk yang dikembangkan.

Proses pengumpulan data dilakukan dengan menggunakan angket, wawancara, tes dan pengamatan. Angket, observasi dan wawancara dipergunakan untuk mengumpulkan data terkait dengan proses pengembangan produk, meliputi analisis kebutuhan dan analisis potensi serta kondisi sekolah akan produk. Angket yang digunakan berupa angket terbuka skala likert dengan jumlah pernyataan 10 soal, wawancara dengan jumlah 13 pertanyaan. Tes digunakan untuk mencari informasi tentang hasil belajar siswa sebelum dan sesudah menggunakan produk yang dikembangkan. Tes yang digunakan berupa tes essay yang bertujuan untuk mendiskripsikan suatu kegiatan sehingga keterampilan sosial dapat diukur. Jumlah soal dalam tes sebanyak 15 soal, dengan validitas soal 0,602 dan reliabilitas $0,61-0,80$.

Analisis hasil belajar didasarkan pada nilai pretest dan posttest. Tes hasil belajar digunakan untuk mengetahui perbedaan hasil belajar siswa sebelum dan sesudah menggunakan Thiagharajan berbasis keterampilan sosial. Perbedaan hasil belajar dianalis dengan uji-t, dengan kriteria uji menerima $\mathrm{H}_{0}$ jika $\mu 1>\mu 2$ yakni $\mathrm{t}_{\text {tabel }}<$ $\mathrm{t}_{\text {hitung }}<\mathrm{t}_{\mathrm{tabel}}$ dengan derajat kebebasan $\mathrm{dk}=\mathrm{n} 1+\mathrm{n} 2-2$ dengan taraf signifikansi $5 \%$.

\section{HASIL DAN PEMBAHASAN PENELITIAN}

Proses pengembangan Project Based Learning berbasis keterampilan sosial dikembangkan dengan model pengembangan model 4-D (four D models) Thiagharajan yang dikelompokan menjadi dua tahapan yaitu tahap pertama menganalisis potensi dan masalah dan tahap ke dua tahap pengembangan yang terdiri dari perencanaan desain, pembuatan desain produk, validasi ahli, perbaikan desain produk validasi ahli dan produk akhir.

Hasil validasi ahli materi terhadap produk mendapat skor rata-rata 4,6 dengan keterangan bahwa model PjBL berbasis keterampilan sosial mata pelajaran PKn siswa layak digunakan dalam pembelajaran PKn pada materi kasus-kasus pelanggaran HAM dalam perspektif pancasila, hasil validasi ahli media mendapat skor rata-rata 4,5 (layak digunakan), hasil validasi ahli desain produk mendapat skor rata-rata 4,57 (layak digunakan).

Langkah selanjutnya adalah uji lapangan, Tabel 1, 2 dan 3 disajikan hasil pengolahan data penelitian, sebagai hasil uji lapangan. 
491 Penerapan Project Based Learning Berbasis Keterampilan Sosial Mata Pelajaran Kewarganegaraan di Sekolah Menengah Atas - Herpratiwi, Taufiqurrahman, Sugeng Widodo, Refki Effendi

DOI: https://doi.org/10.31004/edukatif.v3i2.313

Tabel 1 Paired samples statistics

\begin{tabular}{cc|c|c|c|c}
\hline & Mean & N & Std. Deviantian & Std Eror Mean \\
\hline Pair 1 & $\mathrm{x} 0$ & 74.00 & 14 & 5.575 & 1.490 \\
\hline x1 & 82.79 & 14 & 4.660 & 1.246 \\
\hline \multicolumn{4}{|c}{ Sumbe $:$ spss for windows }
\end{tabular}

Berdasarkan tabel 1 hasil pengolahan data pada tabel paired samples statistics menunjukkan hasil standar deviasi sebelum dan sesudah menggunakan sebesar 5,575 dan 4,660 dengan jumlah sampel 14 rata rata 74 dan 82,79 .

Tabel 2 Paired Samples Correlations

\begin{tabular}{cc|c|c|c}
\hline & N & Correlation & Signifikan \\
\hline Pair 1 x0 \& x1 & 14 & 0,669 & 0,009 \\
\hline \multicolumn{4}{r}{ Sumber: spss for windows }
\end{tabular}

Tabel 2, menunjukkan hasil pengolahan data nilai sebelum dan sesudah penggunaan Project Based Learning berbasis keterampilan sosial didapatkan nilai korelasi sebesar 0,669 dengan signifikasi sebesar 0,009 , artinya 2 variabel tersebut memiliki hubungan kuat dan positif dengan tingkat signifikasi 0,05 lebih besar dari 0,009 .

Tabel 3 Paired samples test

\begin{tabular}{|c|c|c|c|}
\hline & & & Pair 1 \\
\hline & & & $\mathrm{x} 0-\mathrm{x} 1$ \\
\hline & Mean & & $-8,786$ \\
\hline & Std. Deviation & & 4,246 \\
\hline & Std. Eror Mean & & 1,135 \\
\hline & 95\% Confidence Interval & Lower & $-11,237$ \\
\hline & Of the Defference & Upper & $-6,334$ \\
\hline $\mathrm{t}$ & & & $-7,742$ \\
\hline df & & & 13 \\
\hline Sig.(2tailed) & & & 0,000 \\
\hline
\end{tabular}

Tabel 3 terlihat uji nilai $\mathrm{t}-7.742$ pada a $=5 \%: 2=2,5 \%$ (uji 2 sisi) dengan derajat kebebasan (df) $14-1$ $=13$, penggunaan model Project Based Learning berbasis keterampilan sosial dapat meningkatkan keterampilan sosial.

Berdasarkan Tabel di atas menunjukan bahwa hasil pembelajaran dengan menggunakan model pembelajaran memberikan dampak yang positf dikarenakan model tersebut memudahkan siswa untuk memahami langkah dan proses pembelajaran. Hal ini sebanding dengan penelitian yang dilakukan oleh (Insyasiska dkk., 2015). Hasil penelitian keterampilan mengkomunikasikan materi dengan runtut dan penuh percaya diri mencapai $85,8 \%$, hal ini mampu melatih keterampilan berkomunikasi dan berinteraksi secara personal lebih baik bagi siswa. Dengan demikian Project Based Learning dapat melatih keterampilan sosial siswa khususnya pada keterampilan bekerjasama dan berkomunikasi sehingga siswa mampu hidup secara berkolaboratif dan penuh kepercayaan diri dengan lingkungan sekitar (Culclasure et al., 2019).

Pengembangan Project Based Learning berbasis keterampilan sosial, memberikan dampak dalam peningkatan keterampilan sosial siswa. Project Based Learning menurut (Insyasiska dkk., 2015) sebagai pembelajaran berbasis proyek yang inovatif, menekankan belajar kontekstual melalui kegiatan-kegiatan kompleks. Fokus pembelajaran terletak pada konsep-konsep dan prinsip-prinsip inti dari suatu disiplin studi, melibatkan siswa dalam investigasi pemecahan masalah dan kegiatan tugas-tugas bermakna, memberi 
kesempatan kepada siswa bekeria secara otonom untuk mengkonstruksikan pengetahuan yang telah dimiliki sebelumnya, dan mencapai puncaknya yaitu menghasilkan produk nyata (Duke et al., 2019).

Penggunaan Project Based Learning dapat meningkatkan keterampilan sosial siswa, karena siswa diberi waktu dan kesempatan untuk menyelidiki, mencari, menemukan dan memecahkan sendiri masalah materi yang dipelajarinya, sehingga siswa dapat memahami konsep dasar dan memperbanyak pengalaman belajar. Salain itu penggunaan Project Based Learning berbasis keterampilan sosial memberikan pendekatan pembelajaran yang nyata dan mudah dipahami siswa tentang tujuan pembelajaran. Siswa dapat mengorganisasi langkah pembelajaran melalui pedoman dalam model yang dikembangkan (A Munawaroh dkk., 2013).

Penemuan dalam kegiatan pembelajaran dengan menggunakan model yang dikembangkan adalah sikap dan cara siswa belajar lebih mengutamakan kerja sama team dalam menyelesaikan suatu permasalahan yang sedang dihadapi. Project Based Learning memberikan wahana atau tempat siswa saling memberikan ide dan gagasan tentang peristiwa sehingga keaktifan siswa menjadi tujuan utama pembelajaran. Peran dari pendidik atau guru hanya sebagai fasilitator.

Hasil diskripsi di atas sesuai dengan penerepan pembelajaran konstruktivisme, dimana siswa menemukan sebuah permasalahan dan mengembangkan sendiri pengetahuanya, mengingat dan mengungkapkan kembali pengalaman, membandingkan dan mengambil keputusan akan kesamaan dan perbedaan, kemampuan menyukai suatu pengalaman yang satu daripada yang lain, (Jia, 2011). Pembentukan pengetahuan menurut konstruktivis, siswa aktif dalam proses pembentukan kognitif dan keterampilan belajar pada saat berinteraksi dengan lingkungan belajar. (Deesomsak et al., 2014) Pembelajaran menggunakan Project Based Learning menjadi alternative untuk meningkat keterampilan dan pengetahuan siswa. Tujuan penggunaan model bukan hanya untuk memudahkan pendidik memberikan pengetahuan tentang keterampilan-keterampilan tertentu tetapi juga untuk pencapaian kompetensi (Husamah, 2013).

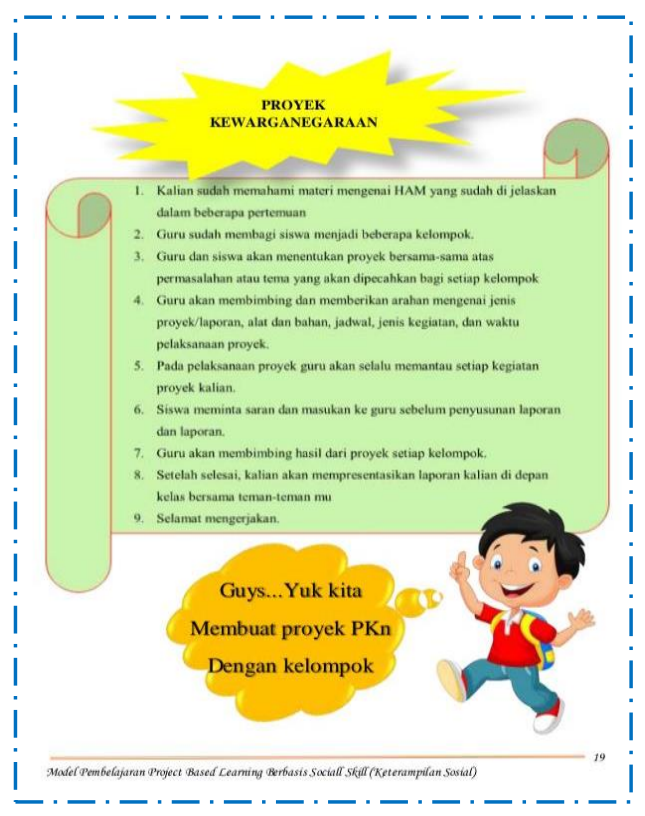

Gambar 1 : Tampilan Proyek PKN

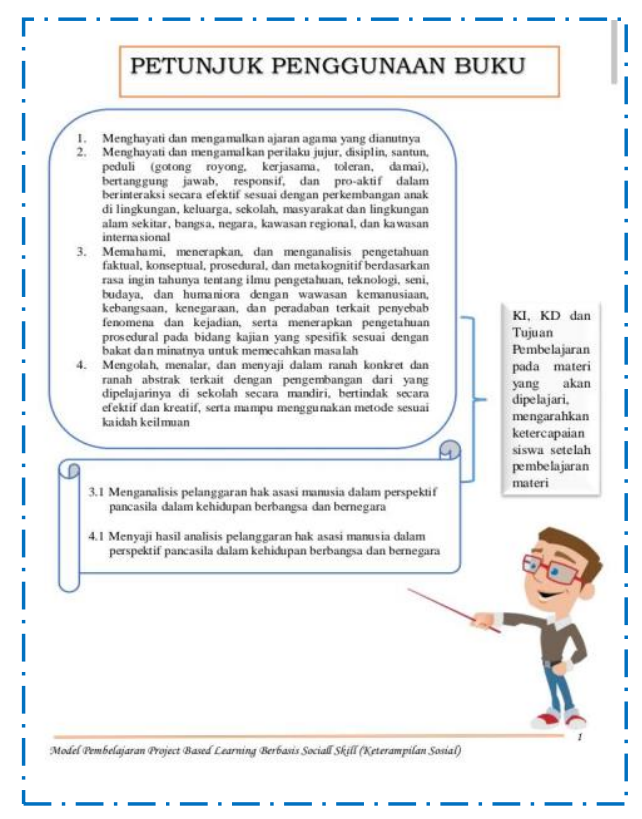

Gambar 2 : Petunjuk Penggunaan Buku 
493 Penerapan Project Based Learning Berbasis Keterampilan Sosial Mata Pelajaran Kewarganegaraan di Sekolah Menengah Atas - Herpratiwi, Taufiqurrahman, Sugeng Widodo, Refki Effendi

DOI: https://doi.org/10.31004/edukatif.v3i2.313

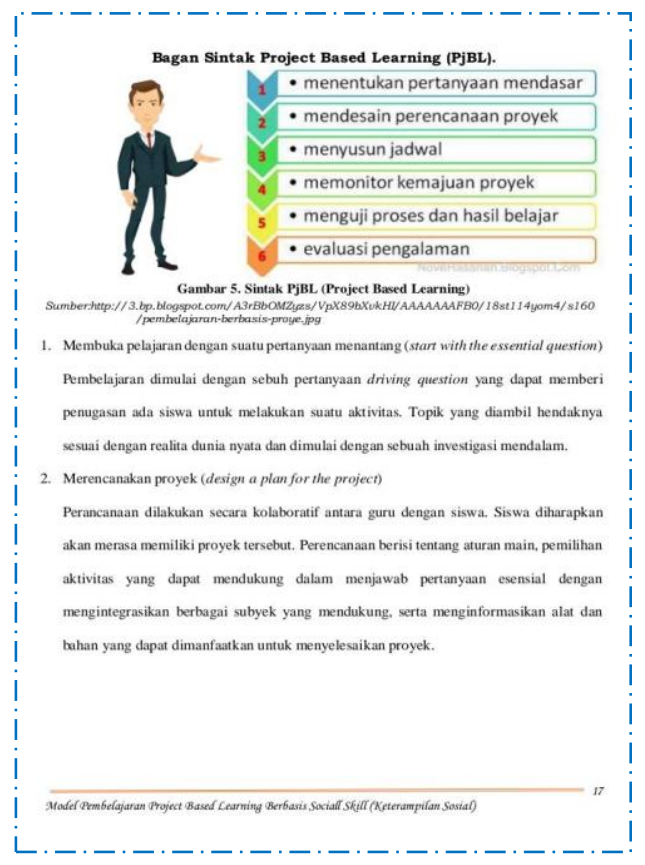

Gambar 3 : Tampilan Sintak PJBL

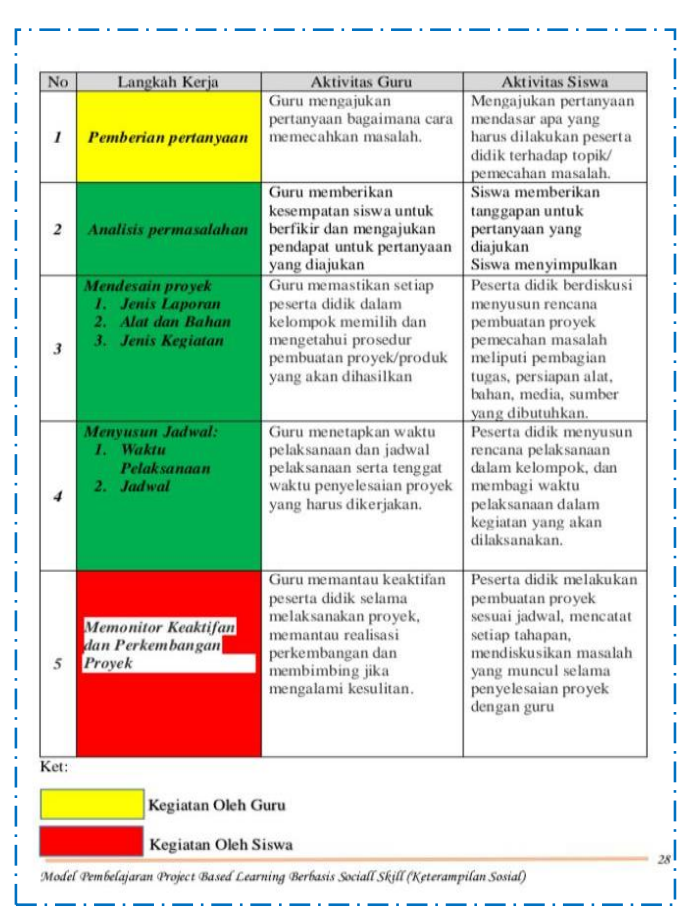

Gambar 5 : Kegiatan Guru dan Siswa

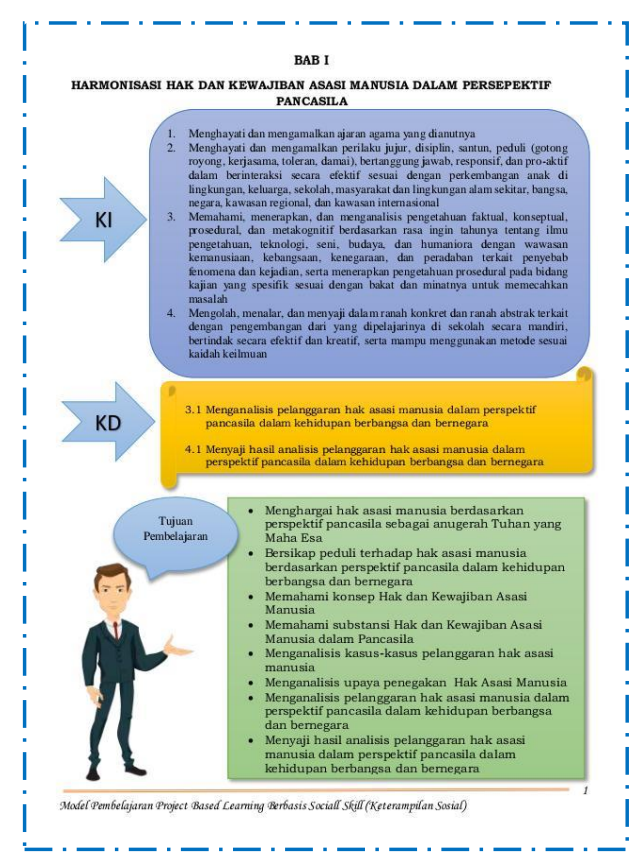

Gambar 4 : Tampilan KI dan KD

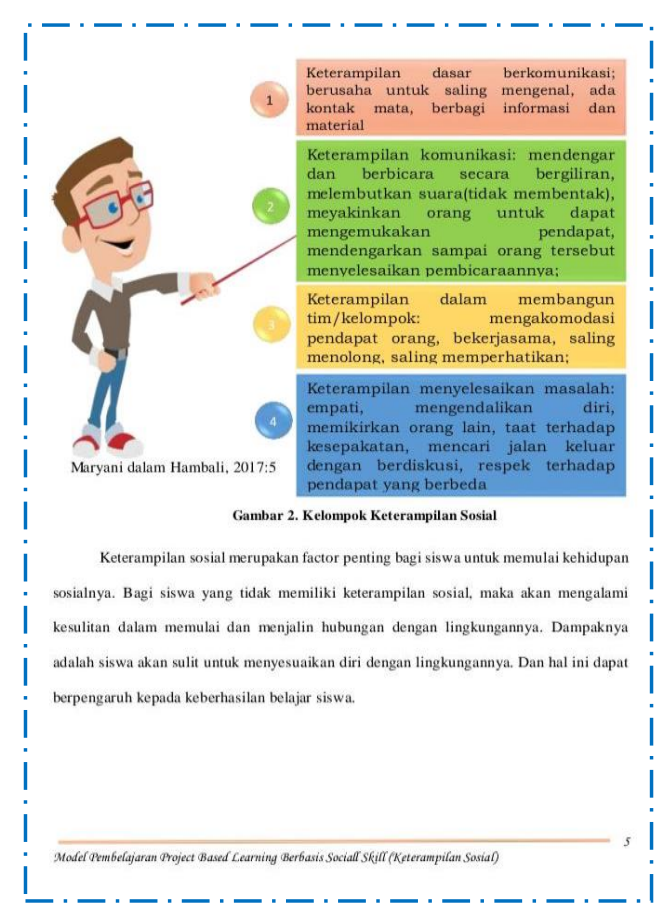

Gambar 6 : Kelompok Keterampilan Sosial

Efesensi pembelajaran diukur dengan indikator utama mengacu pada waktu, (Degeng, 2012). Pada penelitian ini efisiensi yang dihitung adalah efisiensi dari aspek waktu. Pada penelitian ini, penggunaan Project Based Learning yang dikembangkan dapat menghemat waktu pembelajaran. Waktu yang biasa digunakan untuk menuntas tentang materi HAM adalah $5 \times 45$ menit, tetapi setelah menggunakan produk yang dikembangkan siswa dapat menganalisa kasus HAM, konsep materi pokok dan ruang lingkup materi dalam waktu satu pertemuan atau sebanding dengan 2 x 45 menit. 
494 Penerapan Project Based Learning Berbasis Keterampilan Sosial Mata Pelajaran Kewarganegaraan di Sekolah Menengah Atas - Herpratiwi, Taufiqurrahman, Sugeng Widodo, Refki Effendi

DOI: https://doi.org/10.31004/edukatif.v3i2.313

Selain efisien dan keefektifan, peneliti juga mengukur kemenarikan. Menurut (Reigeluth, C.M \& Chellman, 2016). daya tarik adalah kecenderungan siswa untuk ingin terus belajar ketika mendapatkan pengalaman yang menarik. Pengalaman tersebut dapat diperoleh dari pembelajaran yang melibatkan keaktifan siswa dalam pembelajaran, melalui sikap, pengetahuan dan juga tingkah laku. Aspek yang dinilai dari kemenarikan adalah aspek materi, tampilan dan kemenarikan. Bedasarkan hasil penelitian rata-rata persentase materi sebesar 86,42\%, tampilan sebesar 89,3\%, kemudahan dan kemenarikan sebesar 92\%. Secara keseluruhan rat-rata daya tarik adalah $88,85 \%$.

\section{KESIMPULAN}

Project Based Learning berbasis keterampilan sosial mata pelajaran PKN, mampu meningkatkan keterampilan sosial. Penerapan Project Based Learning sebagai intervensi pembentukan keterampilan sosial siswa SMA. Keterampilan sosial sisa meningkat karena dibiasakan untuk menyelesaikan masalah kelompok yang didesain guru dalam sebuah tugas. Keterampilan mengkomunikasikan materi dengan runtut dan penuh percaya diri mampu melatih keterampilan sosial siswa. Dengan demikian Project Based Learning dapat melatih keterampilan sosial siswa khususnya pada keterampilan bekerjasama dan berkomunikasi sehingga siswa mampu hidup secara berkolaboratif dan penuh kepercayaan diri dengan Llingkungan. Penggunaan Project based learning ini mampu meningkatkan keterampilan sosial siswa SMA baik dalam proses pembelajaran maupun dengan lingkungan sekitar, sehingga siswa mampu melakukan komunikasi dengan baik dan lebih percaya diri serta menumbuhkan kreativitas dalam pemecahan masalah.

\section{DAFTAR PUSTAKA}

A Munawaroh, dkk. (2013). Penerapan Model Pembelajaran Berbasis Proyek Untuk Meningkatkan Hasil Belajar Sistem Pencernaan Smp. Journal of Biology Education, 2(1). https://doi.org/10.15294/jbe.v2i1.2619

Anis Shofatun, Muslimin Ibrahim, W. (2016). Pembelajaran Ipa Terpadu Melalui Project Based Learning Dalam Melatihkan Academic. Pendidikan Sains Pascasarjana Universitas Negeri Surabaya, 6(1), 11501158.

Arends. (2014). Model Pembelajaran Inovatif dalam Kurikulum 2013. Yogyakarta : Ar-Ruzz Media.

Cartledge, Gwendolyn \& Milburn, J. A. F. (2016). Teaching Social Skills to Children and Youth. United States : Innovative Approaches. University of Virginia.

Culclasure, B. T., Longest, K. C., \& Terry, T. M. (2019). The Interdisciplinary Journal of Problem-based Learning SPECIAL ISSUE: UNPACKING THE ROLE OF ASSESSMENT IN PROBLEM- AND PROJECT-BASED LEARNING Project-Based Learning ( Pjbl ) in Three Southeastern Public Schools : Academic , Behavioral , and Social-Emoti. Interdisciplinary Journal of Problem-Based Learning, 13(2), 8-30.

Deesomsak, R., Paudyal, K., \& Pescetto, G. (2014). Durham Research Online woodlands. Critical Studies on Security, 2(2), 210-222.

Degeng, I. N. S. (2012). Paradigma Baru Pendidikan Memasuki Era Demokratisasi Belajar. Jakarta: Pustekkomdikbud \& Raja Grafindo Persada.

Duke, N. K., Halvorsen, A. L., Strachan, S. L., Kim, J., \& Konstantopoulos, S. (2021). Putting PjBL to the Test: The Impact of Project-Based Learning on Second Graders' Social Studies and Literacy Learning and Motivation in Low-SES School Settings. American Educational Research Journal, 58(1), 160-200. https://doi.org/10.3102/0002831220929638

Gresham, F. M., \& Elliott, S. N. (2014). Social skills assessment and training in emotional and behavioral 
495 Penerapan Project Based Learning Berbasis Keterampilan Sosial Mata Pelajaran Kewarganegaraan di Sekolah Menengah Atas - Herpratiwi, Taufiqurrahman, Sugeng Widodo, Refki Effendi

DOI: https://doi.org/10.31004/edukatif.v3i2.313

disorders. The Guilford Press.

Husamah, Y. S. (2013). Desain Pembelajaran berbasis pencapaian kompetensi. Jakarta: Prestasi Pustakarya.

Insyasiska, D., Zubaidah, S., \& Susilo, H. (2015). Pengaruh Project Based Learning Terhadap Motivasi Belajar, Kreativitas, Kemampuan Berpikir Kritis, Dan Kemampuan Kognitif Siswa Pada Pembelajaran Biologi. Jurnal Pendidikan Biologi, 7(1), 9-21. https://doi.org/10.17977/um052v7i1p9-21

Jia, Q. (2010). A Brief Study on the Implication of Constructivism Teaching Theory on Classroom Teaching Reform in Basic Education. International Education Studies, 3(2), 197-199. https://doi.org/10.5539/ies.v3n2p197

Kalyoncu, R. (2020). Evaluation of social skills of visual arts teacher candidates according to personality traits. Cypriot Journal of Educational Sciences, 15(3), 554-574. https://doi.org/10.18844/cjes.v15i3.4932

Kurniawan, T. D. (2017). PENGGUNAAN MODEL PjBL UNTUK MENINGKATKAN KREATIVITAS MAHASISWA DALAM MEMBUAT MEDIA PEMBELAJARAN PKN. KALAMATIKA Jurnal Pendidikan Matematika, 2(2), 207. https://doi.org/10.22236/kalamatika.vol2no2.2017pp207-220

Malatuny, Y. G., \& Rahmat, R. (2020). Pembelajaran Civic Education Dalam Mengembangkan Civic Disposition. PEDAGOGIKA: Jurnal Pedagogika Dan Dinamika Pendidikan, 5(1), 56-68. https://doi.org/10.30598/pedagogikavol5issue1page56-68

Maryani, E. (2012). Pengembangan Program Pembelajaran IPS Untuk Peningkatan Keterampilan Sosial. Bandung: Alfabeta.

Muijs, D. \& R. (2018). Effective Teaching Teori dan Aplikasi. Yogyakarta : Edisi kedua Pustaka Pelajar.

ÖZBEY, S., \& KÖYCEĞIZZ, M. (2020). A Study on the Effect of the Social Skill Education on the Academic Self Respect and Problem Solving Skills of the Pre-School Children. International E-Journal of Educational Studies, 4(8), 176-189. https://doi.org/10.31458/iejes.727590

Reigeluth, C.M \& Chellman, A. . (2016). Instructional-Design Theories and Models Volume III. Building a Common Knowledge Base. New York : Taylor \& Francis.

Saavedra AR. (2012). Saavedra 21st_century_skills.pdf. https://doi.org/10.1177/003172171209400203

Trianto. (2014). Mendesain Model Pembelajaran Inovatif, Prograsif, dan Konstektual. Jakarta: Prenada Media Group.

Udin, B. D. (2014). Pendidikan Kewarganegaraan Dalam Perspektif Internasional. Bandung : Widya Aksara Press. 